\title{
RAZA, LINAJE, FAMILIA Y CASA-SOLAR EN EL PAÍS VASCO*
}

por

\author{
JUAN ARANZADI \\ U.N.E.D. Madrid
}

RESUMEN: A la luz de la correlación establecida por E. Todd entre modalidad de estructura familiar y tipo de racismo, el artículo analiza cómo la "raza vasca» de Sabino Arana deriva de un "concepto genealógico» de raza elaborado en el crisol de un "protorracismo religioso» foral deudor del antisemitismo inquisitorial español, de tal forma que, como consecuencia, familia autoritaria, pureza de raza y religión católica se configuran como tres pilares complementarios de la sociedad tradicional vasca a cuyo mítico retorno aspira el racismo sabiniano.

PALABras Clave: Raza. Racismo. Familia. Linaje. Solar. Cristianismo. Antisemitismo.

ABSTRACT: In the light of the correlation established by $E$. Todd between varieties of family structures and kinds of racism, this article analyzes the way in which Sabino Arana's «Basque race» has its roots in a "genealogical concept» of race. This concept was elaborated within a "religious protorracism» related to the Spanish Inquisition's antisemitism, so that, as a consequence, authoritarian family, purity of race and Catbolic religion appear as three complementary pillars of the traditional Basque society, whose mythical return is the aim of Sabino Arana's racism.

KEY WORDS: $\quad$ Race. Racism. Family. Lineage. House. Christianity. Antisemitism.

* Este artículo es un fragmento del capítulo 3 («Racismo, religión y antropología vasca») de un ensayo, El escudo de Arquíloco (Sobre mesías, mártires y terroristas), recientemente publicado en la colección Mínimo Tránsito, de la Editorial A. Machado Libros. 
Apoyándose en una obra de Emmanuel Todd ${ }^{1}$ que postula la determinación por las estructuras familiares de los sistemas culturales de valores básicos y, a su través, de los sistemas ideológico-políticos de las distintas sociedades ${ }^{2}$, P.A.Taguieff ${ }^{3}$ ha incluído los dos tipos principales de racismo que analiza en su libro (el racismo individuo-universalista profesado por el colonialismo francobritánico y el racismo tradicio-comunitarista que alcanza su forma extrema con el nazismo) en el marco más amplio de una tipología que correlaciona «cuatro tipos ideales de racismo» con cuatro de las estructuras familiares que Todd analiza: 1. A la familia autoritaria (Alemania) le corresponde el racismo de exclusión y de exterminio (genocidio); 2. A la familia comunitaria asimétrica (India del Sur), el sistema de castas; 3. A la familia nuclear absoluta (Estados Unidos, Gran Bretaña), el desarrollo separado (apartheid); 4. A la familia nuclear igualitaria (Francia, Portugal central, España central y meridional), el racismo imperialista de dominación y de asimilación (colonialismo, etnocidio).

Dentro de la compleja tipología de estructuras familiares elaborada por Todd, la que aquí más nos interesa es la tipología básica, referida al género de familia característico de cada una de las grandes naciones europeas y elaborada sobre la base de cruzar dos ejes de valores opuestos: «igualdad vs. desigualdad» $\mathrm{y}$ «libertad vs. autoridad» 4

Desde esta perspectiva, Francia del Norte posee una familia nuclear igualitaria (libertad más igualdad entre sus miembros) diametralmente opuesta a la familia autoritaria característica de Alemania (desigualdad más autoridad: «reposa sobre la sumisión de los hijos al padre y la indivisibilidad del patrimonio, aprecia la disciplina pero se burla de la igualdad»); e Inglaterra posee una familia nuclear absoluta (desigualdad más libertad: «exige la independencia de los hijos pero no su igualdad, reconoce la posibilidad de desheredar, un derecho absoluto de las generaciones a ignorarse...reposa sobre una idea mal formulada pero simple, vive y deja vivir, no buscando ni destruir ni integrar las otras culturas») opuesta a la familia comunitaria característica de Rusia (igualdad más autoridad: «combina igualdad y disciplina, equivalencia de los hermanos y obediencia al padre»).

1 La Troisième Plenète. Structures familiales et systèmes idéologiques, Paris, Le Seuil, 1983.

2 «La estructura antropológica, al contrario del sistema ideológico, se perpetúa automáticamente. La familia es, por definición, un mecanismo reproductor de los hombres y de los valores. De forma inconsciente pero inexorable, cada generación interioriza los valores parentales, que definen las relaciones humanas elementales: padres/hijos, hermano/hermano, hermano/hermana, hermana/hermana, marido/esposa. El poder del mecanismo reproductor procede de que puede prescindir de toda formalización consciente y verbal: es automático, infralógico», Todd, o.c.

3 .TAGuiefF, P. A: La force du prejugé. Essai sur le racisme et ses doubles, Gallimard, Paris, 1987.

4 Esta tipología simple se hace más compleja al añadirle nuevos ejes: el carácter endogámico o exogámico del matrimonio, la existencia de normas más o menos constrictivas concernientes a la elección de cónyuge y la existencia de simetría, asimetría o indiferencia como actitud predominante en la relaciones familiares $y$, por ende, sociales.

Hispania, LXI/3, núm. 209 (2001) 879-906 
Y dentro de esos cuatro tipos, el que más nos interesa -porque en él incluye Todd a la familia vasca, junto a, entre otras, la alemana, la escocesa, la irlandesa, la japonesa, la judía y la gitana - es el de la familia autoritaria, caracterizada, además de por los rasgos ya citados, por las actitudes y relaciones asimétricas en su seno y por la elección de cónyuge por los padres: en la familia autoritaria, la desigualdad entre los hermanos está determinada por las reglas sucesorias y de herencia, que estipulan la transmisión íntegra del patrimonio a uno de los hijos; a ello se añaden, como rasgos adicionales, la común residencia del heredero casado con los padres y la excepcionalidad de los matrimonios entre hijos de hermanos. Todd erige como figura simbólica de la familia autoritaria el asesinato cainita del hermano por el hermano, «elegido el uno, excluído el otro...pues el mecanismo de primogenitura o de cualquier otro método de transmisión en bloque del patrimonio paterno, implica rechazo tanto como sucesión».

Ese funcionamiento normal de la familia autoritaria en torno a un doble foco (asesinato simbólico del hermano y desigualdad simple) determina las bases de una configuración ideológica: del mismo modo que la desigualdad de los hermanos implica una visión asimétrica del espacio social, del mismo modo que todos los individuos no tienen en la familia un lugar y un valor equivalentes, así tampoco serán todos los hombres considerados como iguales. De la lista de los grupos humanos que practican un ideal de familia autoritaria, Todd cree poder decir que constituye uun condensado de todos los particularismos, de todos los etnocentrismos, de todos los rechazos de lo universal». La defensa de la familia autoritaria, al implicar la desigualdad entre los hombres (individuales) y los pueblos, aparece fuertemente correlacionada con el culto de la diferencia colectiva (objeto no sólo de búsqueda, sino de invención, hasta el punto de llegar a "percibir diferencias que no existen»), con la obsesión por el tiempo y la continuidad del grupo, con un ideal de arraigo estable y con la biologización de la pertenencia nacional y/o social, de tal modo que el sociocentrismo, parasitando ideológicamente las ciencias bio-antropológicas, se convierte en etnocentrismo con legitimación racial ${ }^{5}$.

Cabe reprochar a Todd un cierto estatismo en su concepción de las estructuras familiares, un olvido o minusvaloración de su evolución, de los cambios históricos experimentados por la familia y el parentesco en las sociedades que analiza, pero por lo que se refiere al País Vasco, todos los rasgos con los que define a la familia autoritaria se registran, como veremos, en la familia tradicional característica del Antiguo Régimen. E igualmente se registra su correlación con el etnocentrismo xenófobo de los siglos XVI a XIX que tiene como heredero ideológico el racismo explícito del primer nacionalismo vasco.

Pero en el caso vasco no sólo hay, como Todd y Taguieff postulan, correlación entre estructura familar autoritaria y racismo heterófobo tradicionalcomunitario, sino que puede descubrirse además una continuidad teórica entre la

5 Los pasajes entrecomillados corresponden a Todd, o.c., p.70-71, 74-75, 104-105. 
ideología sobre la familia y los presupuestos ideológicos del racismo, entre los conceptos de «familia vasca» y de «raza vasca» tal y como ambos se van elaborando entre el siglo XVI y el XX.

Vamos a comenzar el análisis de ese proceso ideológico por el final, por el concepto de raza vasca tal y como aparece en la obra de Sabino Arana.

\section{SABINO ARANA Y LA RAZA VASCA: «RAZA GENEALÓGICA» Y «RAZA BIOLÓGICA»}

Pese a que el propio Sabino Arana invoca la autoridad de los etnólogos como fundamento de su tesis sobre la diferencia sustancial entre la raza euskeriana y la raza española ${ }^{6}$, lo cierto es que no cita nunca a ninguno de esos etnólogos y no se preocupa lo más mínimo por fundamentar científicamente sus dogmáticas afirmaciones. En una de las pocas ocasiones en que se ocupó de las discusiones antropológicas sobre la raza vasca, polemizando con las opiniones expuestas por Unamuno en una conferencia, fue para concluir, con un escepticismo científico que no minó sus convicciones ideológicas, que «el origen de la raza euskeriana desconócese hasta hoy por completo»?.

Lo cual no tiene demasiado de sorprendente si se compara su actitud, por ejemplo, con la postura rigurosamente idéntica que en esa misma época mantiene un autor que no suscribe sus planteamientos nacionalistas, el sacerdote D.Estanislao J. de Labayru. En su Historia General del Señorío de Bizcaya, publicada entre 1895 y 1903 , después de recoger las opuestas opiniones sobre la raza vasca de Manuel Antón, Retzius, Broca, Pruner Bey, Argelliés, el doctor Landa y Telesforo de Aranzadi, Labayru concluye, como Sabino, que «las deducciones, en fin, de la antropología paréceme que nunca saldrán de la esfera de las hipótesis»; lo que no le impide añadir a continuación que «la nación vasca es una raza admirable» y entregarse entusiasta a su abierta apología ${ }^{8}$.

Es indudable que la fuente de la seguridad con la que tanto Labayru como Sabino Arana hablan de la raza vasca no está en las opiniones científicas de los antropólogos europeos y vascos sino en otra parte: en la propia tradición vasca, en la larga serie de autores que desde el siglo XVI habían venido cantando las excelencias del euskera, los Fueros y la nobleza vasca.

6 Arana, Sabino: «Efectos de la invasión», Obras Completas, vol.2, p.1326, Sendoa, San Sebastián, 1980: «Etnográficamente hay diferencia sustancial entre ser español y ser euskeriano, porque la raza euskeriana es sustancialmente distinta de la raza española, lo cual no lo decimos sólo nosotros, sino todos los etnólogos».

7 Obras escogidas. Antología política, L. Haranburu, San Sebastián, 1978, p.184.

8 «Su tipo es interesante. Ofrece el vasco un sello especialísimo que predispone a su favor. Su continente es noble y su forma gallarda...reúne con distinción las dos notas y aspectos más notables de la fisonomía general de la humanidad: la civilización primitiva de los patriarcas medievales y el genio guerrero de los Bárbaros hiperbóreos...creemos que no tardará mucho en desaparecer el carácter eminentemente patriarcal de la raza a no sobrevenir una reacción poderosa entre los eúskaros».

Hispania, LXI/3, núm. 209 (2001) 879-906 
Sin embargo, aunque no fundamente sus convicciones en la raciología científica, es el propio Sabino el que se encarga de contradecir a quienes defienden que no adjudica un significado biológico a la raza vasca, sino étnico, jurídico o político: «el concepto étnico no es jurídico, sino físico y natural, como relativo a la raza...porque pueblo y nación son vocablos que se refieren a la raza y no al derecho»?.

Es también el propio Sabino el que desmiente que la raza vasca se confunda o identifique con la lengua vasca (el euskera), con la cultura vasca o con las instituciones (los Fueros). No sólo no se confunde con ellas, sino que éstas son secundarias e inesenciales en comparación con la raza, hasta el punto de que sin ésta carecen absolutamente de valor:

«No cabe decir lo mismo de la raza porque es evidente que, extinguida ésta, queda extinguida su sociedad para ser reemplazada por otra. Si desapareciese nuestra raza de estas montañas, y en éstas y con el nombre de Euskeria se constituyera la confederación de sus seis estados parciales, y cada uno de éstos se estableciera con la respectiva tradición de nuestra raza, con nuestra lengua y hasta con nuestras costumbres y carácter, esta Euskeria no sería nuestra Patria, sino otra Euskeria diferente: extinguidos los miembros de una familia, extinguida queda la familia misma»10.

En ese texto Sabino hace sinónimos «raza»y «familia», mientras en otros «raza» equivale a «conjunto de familias con un mismo origen» y a «gran familia». En cualquier caso, ambas, «familia» $\mathrm{y}$ «raza», concebidas como un «objeto natural»:

«Hablamos de raza en el sentido de conjunto de familias que proceden directamente de un mismo origen más o menos remoto. En este sentido concreto, 'ra-

9 Obras Completas, vol. 2, p.1326.

10 Obras Completas, vol.2, p.1328, nota 2. La prioridad de la raza sobre la tierra, sobre la lengua, sobre la cultura y sobre los Fueros, aparece clara en otros muchos textos de Sabino Arana: «ies acaso la tierra que pisamos lo que constituye la patria?, ¿qué más nos da tener una Bizkaya libre aquí en estas montañas como tenerla en otra parte?...Si se diera una Bizkaya, libre sí, pero constituida por la raza española, ¿sería en verdad Bizkaya?...Si fuera moralmente posible una Bizkaya foral y euskalduna (con euskera), pero con raza maketa, su realización sería la cosa más odiosa del mundo, la más rastrera aberración de un pueblo, la evolución política más inicua y la falsedad más estupenda de la historia...Si nos dieran a elegir entre una Bizkaya poblada de maketos que sólo hablasen Euskera y una Bizkaya poblada de bizkainos que sólo hablasen el castellano, escogeríamos sin dubitar esta segunda, porque es preferible la sustancia bizkaina con accidentes exóticos, que pueden eliminarse y sustiruirse por los naturales, a una susancia exótica con propiedades bizkainas que nunca podrían cambiarla». Cit. en Corcuera, Orígenes, ideología y organización del nacionalismo vasco (1876-1904), Ed.Siglo XXI, Madrid, 1979, p.385. Para Sabino, la sustancia inmutable de la nación es lo que en ella hay de natural, de biológico: la raza; lo demás es accidental, artificial, mutable, cambiable. 
za' es lo mismo que 'nación, gente o pueblo'; designa a una gran familia y expresa un objeto natural, que existe independientemente de la voluntad de los hombres»11.

En este sentido, tiene en parte razón Zulaika cuando, apoyándose en Urla, defiende que "Arana utiliza estas nociones de raza y sangre en el sentido tradicional de descendencia de grupo o linaje, comparable a la noción de gens de Morgan» ${ }^{12}$. No la tiene sin embargo cuando añade que «su noción de raza no es la de la antropología racialista», al menos si entre esos antropólogos se incluye a Morgan, calificado por Marvin Harris como racista con sobrados motivos ${ }^{13}$.

Hay en la obra de Morgan, no sólo la misma equiparación terminológica entre «raza» y «familia» que en Sabino Arana, sino incluso, en algunos pasajes, una identificación entre «familia» y «especie». Refiriéndose a su famosa secuencia de siete estadios evolutivos, escribe Morgan, en Ancient Society ${ }^{14}$, que es «históricamente verdadera para toda la familia bumana, al márgen del estadio alcanzado por cada rama respectivamente», y añade, en una nueva oscilación terminológica, que, si bien "la porción más avanzada de la raza bumana» se detiene periódicamente, «desde el período medío de la barbarie, sin embargo, las familias aria y semítica parecen representar adecuadamenete las tendencias centrales del progreso, que en el período de civilización ha sido asumido gradualmente sólo por la familia aria».

Si a ésto añadimos que lo que Morgan llamó gens es lo que en el vocabulario técnico de la Antropología del Parentesco se designa como clan y que un clan se define como un grupo de filiación formado por un conjunto de linajes o de familias que postulan descender de un antepasado común aún cuando no sean capaces de trazar las relaciones genealógicas que les vinculan con él (es decir, lo que Sabino Arana llama «raza», «conjunto de familias con un origen común» o "gran familia»), llegaremos a la conclusión de que, tanto en la antropología racista de Morgan como en la ideología racista de Sabino Arana, el término raza - como también el término nación - se utilizan con frecuencia como tér-

11 Obras Completas, vol.3, pp. 2264-5. Las cursivas son mías: tan importante como la concepción de la raza como un "objeto natural», es su definición como algo que «no depende de la voluntad humana». Sabino insiste en que quien es de raza vasca no puede dejar de serlo para pasar a ser, por ejemplo, de raza española, del mismo modo que, para los nacionalistas étnicos, no se puede dejar de pertenecer al pueblo vasco o al pueblo español para pasar a pertenecer, por voluntad propia, al pueblo alemán o al pueblo judío: se trata, para los racistas y para los nacionalistas, de una imposibilidad ontológica, pues, según su concepción, raza y etnia no dependen de la voluntad humana. En la constelación ideológica de la modernidad, en cuyo marco se discuten los problemas étnicos y nacionales - los problemas de los derechos de los individuos y los derechos de los pueblos-, la oposición comunitarismo vs. individualismo se cruza con otra aún más importante: naturalismo vs. artificialismo (y con su homóloga, sustancialismo vs. voluntarismo).

12 ZUlaiKa, Joseba: Del Cromañón al Carnaval, Erein, San Sebastian, 1996, p.66.

13 En HARRIS, Marvin: El desarrollo de la teoría antropológica, Siglo XXI, Madrid.

14 Citado por George W. Stocking, jr., Race, Culture and Evolution, The University of Chicago Press, 1982, p.118

Hispania, LXI/3, núm. 209 (2001) 879-906 
minos pertenecientes al vocabulario del parentesco (del parentesco, habría que añadir, en tanto que relación socialmente postulada que puede coincidir o no con la relaciones biológicas que se anudan en el proceso de reproducción, tal y como éste es concebido en las diferentes culturas).

Es necesario recordar aquí que, desde que precisamente Morgan inaugurara el estudio antropológico del parentesco, los antropólogos han venido debatiendo sin cesar y sin ponerse de acuerdo sobre la relación entre el parentesco como hecho social y el parentesco como hecho biológico, entre las relaciones genealógicas culturalmente postuladas y las relaciones genéticas biológicamente establecidas ${ }^{15}$

Obviamente, no vamos a entrar aquí en esa discusión, pero merece la pena tenerla presente para entender en toda su significación qué es lo que implica considerar que el término "raza» — a semejanza del término «gens» o "clan»— pertenece de pleno derecho, en sus usos vulgares y en algunos de sus usos por los primeros antropólogos racialistas, al vocabulario del parentesco. Propongo llamar concepción genealógica de la raza a la que subyace a esos usos, según los cuales se entiende por raza un grupo de individuos «emparentados» por la postulación indemostrada de un orígen común.

Ciertamente, no es ése el significado principal del término «raza» en el ámbito del que lo toman en préstamo las ciencias humanas del siglo XIX, es decir la zoología, y más en concreto la zoología aplicada a la selección artificial eugenésica, destinada a la producción doméstica de "pseudo-especies» animales dotadas de determinadas características deseables hereditariamente transmisibles. Ese origen explica que, para la raciología científica decimonónica, el término «raza» designe fundamentalmente, al principio, a un grupo humano con características físicas comunes transmisibles por herencia. Propongo llamar a esta acepción del vocablo concepción zoológica o biológica de la raza.

Lo cierto es que no es fácil pensar una concepción sin la otra, una acepción del término «raza» sin la otra: del «origen común» se deriva una «sustancia común» y los «rasgos comunes» hacen pensar inevitablemente en «ancestros comunes». Como escribe Stocking:

«En términos de sentido común la idea de raza está construida no sólo sobre la noción de semejanza, sino también sobre la idea de consanguinidad. Una raza es un grupo de individuos que comparten ciertas características en virtud de su común ascendencia» 16 .

is La tendencia «cultural» y la tendencia «biológica» han llegado en la actualidad al punto máximo de separación: mientras algunos antropólogos de tendencia simbolista declaran que el parentesco es una concepción biologista etnocéntrica proyectada por nuestra cultura sobre otras culturas que no asignan relevancia social alguna a las relaciones genealógicas, otros antropólogos de tendencia sociobiólogica lo consideran un universal cultural de raíz biológica y concentran su atención en el estudio del parentesco entre los primates.

16 Cf. STOCKING, o.c., p. 164. 
Es más, puede decirse que, en la evolución del concepto científico de raza, se registra un progresivo deslizamiento desde la inicial «concepción biológica de la raza» (una concepción sustancialista, clasificatoria, estática) hacia una variante científica, evolucionista, genetista, de la «concepción genealógica de la raza»: «Los antropólogos físicos partieron de una concepción poligenista preevolucionista de raza pura como una conjunción de rasgos manifiesta en todo miembro individual de la raza, esencialmente inalterada por el tiempo o las circunstancias» ${ }^{17}$; a medida que la semejanza racial se fue concibiendo más como un fenómeno estadístico que como la manifestación individual de una sustancia racial común, se fue imponiendo una concepción tipológica de la raza que, al tiempo que problematizaba la presunta ascendencia común, demandaba una explicación diacrónica de la distribución de las semejanzas y diferencias entre los individuos. Y a medida que el evolucionismo se imponía en biología y en antropología, el anti-esencialismo darwiniano, que ni siquiera respetaba la concepción sustancialista de las especies, minaba inevitablemente cualquier concepción de las razas humanas como esencias inmutables y perdurables a lo largo del tiempo.

Pero no adelantemos acontecimientos. Quedémonos simplemente con la posibilidad de considerar el término «raza» como perteneciente al vocabulario de los grupos de parentesco, con la distinción entre concepción genealógica y concepción biológica de la raza, y volvamos a Sabino Arana.

\section{RAZA Y RELIGIÓN EN SABINO ARANA}

La concepción que Sabino Arana tiene de las relaciones entre raza vasca y religión católica, así como su interpretación de la legislación foral vizcaína, que impedía el asentamiento de «extranjeros» en tierra vasca — calificada por Caro Baroja como «anticipo de leyes raciales»- las expone con meridiana claridad en su polémica con el carlista Echave-Sustaeta y Pedroso a propósito de los Fueros vasco-navarros ${ }^{18}$. El objeto de la polémica son las leyes XIII y XIV del Título I del Fuero Nuevo de Vizcaya de $1526^{19}$, en el que se proclama la hidalguía colectiva, la nobleza y la limpieza de sangre de todos los vizcaínos, y se impide morar y avecindarse a moros, judíos y conversos ${ }^{20}$.

17 Cf. Stocking, o.c., p. 163.

18 Me he ocupado extensamente de esta polémica en Milenarismo vasco, Taurus, Madrid, 2000, pp.466-470. Las citas de Sabino Arana proceden de «El Partido Carlista y los Fueros vaskonavarros», Obras Completas.

19 Cf. Fuero Nuevo de Vizcaya; ed. de Leopoldo Zugaza, Durango, 1976

20 Dicen así: «Que porquanto todos los dichos Vizcaynos son Hombres Hijos-Dalgo, y de Noble Linaje, e limpia Sangre, e tenían de sus Altezas Merced, y Provission Real, sobre, y en razón, que los nuevamente convertidos, de Judíos, e Moros, ni Descendientes, ni de su Linaje, no puedan vivir, ni morar en Vizcaya». Siguen $-\mathrm{y}$ se prolongan en la Ley XIV, o Provisión Real sobre los nuevamente 
Sabino Arana entiende que con estas leyes los vizcaínos intentaban «preservarse del contagio del pueblo español» por temor a que hubiera «entre sus antepasados algún moro o algún judío» ${ }^{21}$. Echave-Sustaeta, por su parte, piensa que el rechazo era de carácter religioso y no racial, pues lo que deseaban los vizcaínos era «evitar el roce con los no católicos» ${ }^{22}$. La contra-argumentación de Sabino Arana no tiene desperdicio. Empieza por recordarle a Echave que no todo el Fuero de Bizkaya está escrito y que, por tanto, para interpretar su letra hay que atender a su espíritu general, tras lo cual declara que, dado el «españolismo» del carlista,

«tiene por fuerza que juzgar las leyes bizkainas con un criterio exótico y peregrino, y allí donde vea la palabra moros o judíos, atribuirla al espíritu religioso, y no al de raza. Porque en efecto: mientras éste nunca informó ley alguna española, porque la raza española nunca fue raza, sino un producto informe de la mezcla de varias y diversas gentes, leyes bizkainas hay de carácter fundamental que están inspiradas en la natural repugnancia que sentían las familias bizkainas a enlazarse con las extrañas, por la conciencia más o menos clara que tuvieron de su raza primitiva y singularísima $\mathrm{o}$, más probablemente, por otras causas que no hay por qué apuntar. $\mathrm{Y}$ de aquí se sigue que, mientras las palabras moros y judíos que aparecen en la legislación de España siempre han de entenderse expresivas de profesión religiosa, su presencia en las leyes bizkainas, por el contrario, puede muy bien obedecer al espíritu de raza, y no al religioso».

En su argumentación, Sabino se apoya en el primer considerando de la Ley XIII («Por quanto todos los vizcaynos son Hombres Hijos-Dalgo, y de Noble Linaje, é Limpia Sangre») para preguntarse a continuación:

convertidos - las medidas, informes y averiguaciones («se averigue ser de limpia sangre») destinados a evitar el asentamiento de conversos, pues «algunas de las personas de las nuevamente convertidas a nuestra Santa Fe Católica, de judíos y moros y linaje de ellos, por temor que tienen de la Inquisición e por ser essentos y decir ser Hijosdalgo, se han passado, y passan de estos mis Reynos, y Señoríos de Castilla, a vivir, y morar en algunas Ciudades, Villas y Lugares del dicho Condado, e Señorío de Vizcaya; e que si no se remediase se podían recrecer algunos daños e inconvenientes en mucho deservicio de Dios y mío"; se impide que los conversos se puedan avecindar y se ordena a los que ya lo estuvieren «y Linajes de ellos...se vayan y salgan fuera de los dichos Lugares, e sus Términos».

21 Continúa Sabino: «Para estar avecindado en Bizkaya y ser ciudadano bizkaino era preciso: o ser originario de raza, o ser extranjero que hubiese probado no haber entre sus ascendientes ninguno de casta de moros o judíos. Esta ley creyeron suficiente los bizkainos para preservarse del contagio del Pueblo Español (que era el extranjero con quien más rozaban), pues sabido es lo difícil que sería hallar un español que no tuviese entre sus antepasados algún moro o algún judío, ya que moros y judíos habían habitado durante muchos siglos en España y cruzádose con la población indígena, la cual, a su vez, era producto de varias y muy diversas razas que habían invadido dicha tierra».

22 Escribe Echabe: «Los bizkaínos querían rechazar a los castellanos, no por ser maketos, sino por ser (los que lo fueran) judíos o moros. Querían, pues, evitar el roce con los no católicos, no con los castellanos por ser castellanos, como lo prueba el hecho de encontrar a cada momento gente de procedencia castellana ocupando cargos de representación popular en Bizcaya...los bizcainos no quisieron preservarse del pueblo español, como usted dice en su Hoja, sino de los moros y judíos con capa de cristianos».

Hispania, LXI/3, núm. 209 (2001) 879-906 
«Ahora bien, ¿qué significa esa Hidalguía, esa Nobleza y esa Limpieza de Sangre (que todo viene a ser uno) en boca de bizkainos? Ni más ni menos que lo que hoy llamamos pureza de raza...¿Por qué entonces los bizkainos hablaron sólo de moros y judíos y no aludieron a las otras razas? Porque en el tiempo que hicieron la ley no tenían que temer otras inmigraciones» 23 .

Hasta aquí, el racismo sabiniano no es más que una prolongación, una profundización, una exacerbación del protorracismo español prerracialista, cristianoviejo, de fundamento religioso. El rechazo "católico-español» de moros y judíos se prolonga en rechazo "católico-vasco» de los españoles: los vizcaínos rechazan a los españoles porque sospechan que se han mezclado con moros y judíos, porque son cristianonuevos, probables descendientes de "marranos» y «moriscos»y, en cuanto tales, portadores de irreligión e inmoralidad. Esta línea de argumentación, que vuelve el racismo español contra los propios españoles y que convierte el anti-maketismo vasco en directa derivación del antisemitismo español (tanto judeofóbico como antiárabe), alegando una motivación religiosa (el contacto maketo como fuente de pecado y de degradación moral y religiosa) es muy frecuente en Sabino Arana.

Pero también lo es otra que privilegia claramente lo racial sobre lo religioso:

«que era ley de raza y no de religión - continúa Sabino- lo demuestra la misma letra de la ley, porque no prohíbe la entrada en el territorio sólo a moros y judíos, sino a cualquiera de su linaje, fuese bisnieto, tataranieto o más remoto descendiente, y sin reparar en si permanecían o no en el error, o en si eran buenos o malos conversos» 24 .

23 Y continúa: «Que para entender las leyes es preciso conocer el carácter de la época en que se escriben. Cuando los bizkainos la escribieron (en 1526) vieron que era el único remedio contra la repetida inmigración de moros y judíos y judaizantes, que perseguidos en España por la Inquisición se pasaban a Bizkaya para naturalizarse en ella y así salvarse de la justicia española...ya para entonces, otro tanto se había extendido la secta en España, que estuvo a punto de hacerse totalmente judía dicha nación latina, y que si el pueblo español dio muchas veces contra las aljamas fue simplemente por espíritu de bandidaje y no religioso: las razas árabe y hebrea habíanse ya enlazado con la española e inoculándola el virus anticristiano, y judíos y judaizantes había numerosísimos en la nobleza española, y judíos y judaizantes hasta en el clero y en los mismos conventos...De donde se deduce que sólo con esta ley, y aun cuando los bizkainos no tuviesen (que sí la tenían) otra no escrita y referente a la pureza de raza, se preservaban de hecho del contagio del pueblo español».

${ }_{24}$ Y sigue: «Tan ley de raza era la bizkaina que nos ocupa, que no sólo estuvo vigente en el siglo XVI, sino que también se aplicó con todo rigor en el XVII, en el XVIII y aún en éste en que vivimos, es decir, cuando de España no podían ya venir ni moros ni judíos porque habían sido expulsados de su territorio. Ni en este mismo siglo ha podido obtener ningún español carta de naturaleza bizkaina, si antes no hubo demostrado no contar entre sus ascendientes ninguno de casta de moros o judíos».

Hispania, LXI/3, núm. 209 (2001) 879-906 
Y completa su argumentación alegando que esa ley no hacía sino reflejar la antiquísima costumbre de reservar el derecho de «ciudadanía» a los autóctonos, a los nacidos en tierra vizcaína:

«Era ésta la de no ser bizkaino y no tener, por consiguiente, ni voz ni voto en ninguno de los asuntos de la verdadera Bizkaya, que eran las Anteiglesias, ninguno que no fuese originario».

Sabino Arana tiene toda la razón al alegar que la persecución inquisitorial y foral a los conversos y a sus descendientes - marranos o moriscos de primera, segunda, tercera o cuarta generación- supone la consideración de la «mancha religiosa» como algo hereditario, algo biológicamente transmitido, y por tanto la transformación de una discriminación religiosa en discriminación «racial» (el primer paso en la transición moderna, culminante en el nazismo, desde la judeofobia religiosa, que dejaba como posible salida la conversión, hasta el antisemitismo biológico, que deja como única solución posible la expulsión o el exterminio).

Pero por esa vía sólo obtenemos la genealogía antisemita del maketo, no la genealogía ideológica de su opuesto, de «la raza vasca». Para entender la directa vinculación entre ésta y la condición vizcaína de «Hijo-Dalgo, de Noble Linaje é Limpia Sangre», es preciso que nos detengamos en los sucesivos eslabones de la elaboración "mitológica» que lleva desde Zaldibia a Sabino Arana pasando por Echabe y Larramendi.

\section{HIDALGUÍA COLECTIVA, LIMPIEZA DE SANGRE Y «RAZA VASCA»}

El carácter diferencial del desenlace de la crisis bajo-medieval en el País Vasco con respecto a otras áreas de los Reinos cristianos peninsulares fue la conquista - para todos los vizcaínos y guipuzcoanos, y para los pobladores de algunas comarcas de Alava y Navarra- de la hidalguía colectiva plasmada en la legislación foral ${ }^{25}$.

Basicamente, ello supuso la extensión a la «tierra llana», la generalización a la totalidad de los pobladores de Vizcaya y Guipúzcoa, de ciertos privilegios «burgueses» (la prohibición de ser sometido a tortura; la exención de determinados impuestos reales, de pagar pechas serviles y de ser llamado a levas milita-

25 Trato con detalle los distintos aspectos de ese importante proceso histórico en varios capítulos de Milenarismo vasco, o.c., Segunda Parte, I, 2, pp. 163-183, y Tercera Parte, Capítulo 1, 2, C, a: «La hidalguía colectiva: historia y plasmación foral», pp. 440-449. A la bibliografía allí utilizada y citada, hay que añadir un análisis reciente que confirma las líneas generales y las conclusiones allí obtenidas: el magnífico trabajo de José María Portillo Valdés, «República de hidalgos. Dimensión política de la hidalguía universal entre Vizcaya y Guipúzcoa», recogido en La lucha de Bandos en el País Vasco: de los Parientes Mayores a la bidalguía universal, Editado por José Ramón Diaz de Durana y Ortiz de Urbina, Universidad del País Vasco, Bilbao, 1998. 
res) concedidos por el Rey a los habitantes de las villas que le habían ayudado a domeñar a la levantisca nobleza. Lo que esa conquista tuvo en el País Vasco de «tácita sentencia arbitral» entre los interses de las distintas clases sociales, explica que la legislación foral sancionara también, al mismo tiempo, la política nobiliaria de defensa del mayorazgo y el derecho de familia correspondiente, caracterizado por la obligación de mantener indiviso el patrimonio familiar, por la libertad paterna para elegir heredero entre los distintos hijos y por la transmisión del patrimonio indiviso propter nuptias del matrimonio heredero (rasgos todos ellos de lo que Todd, como vimos, clasifica como familia autoritaria proclive a la generación de racismo heterófobo).

Aunque tanto los Fueros como los privilegios «hidalgos» que sancionaban constituían una clarísima novedad jurídico-política en relación a la situación social anterior, y aunque (como el resto de los fueros de otras villas y comarcas de los Reinos cristianos peninsulares que, en algunos casos, sirvieron a los vascos de modelo) no podían revestir otra forma, dado el orden socio-político de la época, que la de concesiones legales de los Monarcas a sus súbditos, la apología y defensa de los mismos frente a sus críticos en la Corte, y más adelante frente a los intentos «centralistas» por suprimirlos, recurrió a una estrategia retórica centrada en la inversión mitológica del proceso histórico efectivo: los Fueros se presentaron como una simple recopilación escrita de unos «usos y costumbres» cuyo origen se perdía en la noche de los tiempos, y la hidalguía colectiva como el reconocimiento legal de la ancestral nobleza universal de vizcaínos y guipuzcoanos.

La legitimación legendaria de esa tradición inventada generó, entre los siglos XVI y XIX, una prolija «mitología» cuyos distintos ciclos temáticos se exigían mutuamente y se reforzaban ideológicamente entre sí. La nobleza universal de los vizcaínos (término general con el que pronto empezó a designarse a los pobladores tanto de Vizcaya como de Guipúzcoa) alegó como su origen y fundamento el desembarco en tierra vasca del patriarca bíblico Túbal, hijo de Jafet y nieto de Noé, primer poblador de la península ibérica y de quien "procede toda nobleza» (tanto la de todos los «vizcaínos» como la del Rey de España, cuyo derecho al trono se legitima en virtud de esa descendencia de Túbal, primer monarca de España). Remontándose a Túbal, esa nobleza originaria se vio pronto bendecida por la tempranísima cristianización de los "vizcaínos», quienes, nobles y cristianos todos desde la primitiva población de la tierra vasca y española, se habrían mantenido limpios e incontaminados de todo contacto con los invasores posteriores: celtas, romanos, godos, árabes, y — sobre todo-moros y judíos.

Para la «mitología» vasco-iberista, que Humboldt hizo suya y difundió entre los románticos europeos, los vascos son los descendientes de los antiguos iberos (de los pobladores originarios de la península) y el euskera la lengua que éstos hablaban. Para la complementaria «mitología» vasco-cantabrista, que tuvo también su prolongación científica ${ }^{26}$, fueron los vascos los protagonistas

26 Entre otros textos, en Los Pueblos del Norte de Julio Caro Baroja, donde éste aplica al área vasco-cantábrica la teoría de los ciclos culturales de la Escuela Histórica de Viena»

Hispania, LXI/3, núm. 209 (2001) 879-906 
de lo que las fuentes históricas recogen como resistencia cántabra frente a la penetración romana (las «guerras cántabras»), resistencia que les permitió mantenerse libres de toda mezcla con los invasores. Como limpios y puros de toda mezcla con godos, árabes, moros y judíos, se mantuvieron asimismo los vizcaínos en siglos posteriores, conservando incólume, como consecuencia, la limpieza de sangre y la condición de cristiano viejo.

Al reivindicarse como cristianos viejos, limpios de sangre mora o judía, hidalgos y nobles todos, los "vizcaínos» convirtieron en criterio de discriminación étnica (que por primera vez suministró una autoconciencia colectiva diferencial a un grupo social - los futuros «vascos»- constituyéndolo como un grupo étnico) lo que, en el ámbito más amplio de la Monarquía Española de los Reyes Católicos y de sus herederos, funcionaba como un criterio estamental de jerarquización social: la posesión o ausencia de nobleza, que distinguía y separaba a los grupos sociales en el interior de España, constituyó para los «vizcaínos», hidalgos todos, un criterio de distinción y separación con el exterior, una frontera étnico-territorial sancionada por la legislación foral.

Y el núcleo central de la «mitología» que legitimó esa etnogénesis fue el mito de la continuidad física, biológica, genealógica, en una misma tierra, de una misma población configurada como un mismo pueblo, con la misma lengua, la misma religión, la misma cultura, los mismos «usos y costumbres» y las mismas «leyes viejas» (recogidas en los fueros), desde los orígenes hasta hoy.

En ese marco «mitológico» tiene lugar la elaboración ideológica que desemboca en el concepto sabiniano de raza vasca. Y esa elaboración empieza bien pronto, tanto en Vizcaya como en Guipúzcoa.

En Vizcaya, entre el Fuero Viejo (1452), que «suponía la existencia de diversos órdenes de vizcaínos (labradores e hidalgos) y mantenía una relación señorial de dominio compartido del territorio" ${ }^{27}$, y el Fuero Nuevo (1526) - sobre cuya interpretación hemos visto discutir a Sabino Arana y al carlista Echave Sustaeta-, se produce una

«significativa invención, la de una comunidad de bidalgos...dueños patrimoniales tanto del territorio como del conjunto de privilegios y libertades que el propio Fuero contenía», invención ésta de la hidalguía colectiva de la que "se deducía que era la propia tierra de Vizcaya la que atribuía tal estado, no la probanza personal de la misma según los requerimientos del Derecho» 28.

Fue el licenciado Andrés de Poza ${ }^{29}$ el primero que, en polémica con el fiscal de Valladolid, Juan García, elaboró la doctrina justificatoria de la reciente invención, basada

27 Portillo, José María: o.c., p.427.

28 PORTILlo, o.c., p.428-429.

29 PozA, Andrés de: Fuero de bidalguía. Ad pragmaticas de Toro et Tordesillas, Edición y estudio introductorio de Carmen Muñoz de Bustillo, Bilbao, 1997.

Hispania, LXI/3, núm. 209 (2001) 879-906 
«en una peculiar interpretación del solar como referente de la bidalguía y del infanzón como sujeto patrimonial del mismo...el solar a que hacía referencia la idea de universalidad de la hidalguía vizcaína era, precisamente, la tierra de Vizcaya, toda ella. Vizcaya, más que el Señorío, constituía un solar capaz de ser reputado como continente de hidalgos, porque constituía una referencia común de linaje para todos los vizcaínos originarios...en esa referencia de linaje común, y no propiamente en una aséptica tierra, estaba la referencia esencial; lo esencial era la calidad que la tierra, como solar toda ella, era capaz de transmitir como cualidad»30.

La argumentación «jurídica» de Poza exigía apoyarse en «historias», elaborar «mitos»:

«Que Vizcaya fuera solar de infanzones significaba que toda la tierra de Vizcaya podía asignar status, ser fuente indudable del mismo corporativamente disfrutado por los hidalgos infanzones vizcaínos. La cuestión prinicpal estaba por tanto en mostrar que Vizcaya constituyera solar, que tuviera cualidades que dejaran fuera de duda esta capacidad del territorio mismo. Es ahí donde encajaban perfectamente unas bistorias, medio perfectamente probatorio en la cultura moderna y que Poza contribuyó como nadie a forjar. La suposición de un poblamiento original, la desconexión de dependencia respecto a imperios y dominios extraños, especialmente por su relevancia cultural el romano, capacidad para confederarse con formas políticas complejas como ese mismo imperio o la monarquía gótica, eran todas historias que demostraban (en el más literal de los sentidos jurídicos) que Vizcaya era solar. Pero sobre todo lo hacía el hecho de que esa misma tierra hubiera constituido, tras la 'pérdida de España', un reducto desde el que se procediera a su recuperación y salvación. La tierra vizcaína podía reputarse por solar conocido por la sencilla razón de que era el solar, es decir, el lugar desde el que España había renacido. Vizcaya era solar conocido porque era la vagina de la que había nacido España. Este argumento conllevaba también una necesaria suposición: Vizcaya era una república... adherida a la monarquía bajo el mantenimiento de una constitución propia que se sustanciaba en el Fuero, en el nuevo de 1526 que era condensación de su derecho y costumbre»31.

No creo necesario enfatizar la larga perduración, a través de Sabino Arana y hasta el «soberanismo» del nacionalismo vasco en la actualidad, de la última parte de la argumentación de Poza. Pero no es eso lo que ahora nos interesa, sino la relación entre la concepción de Vizcaya como un solo solar de hidalgos, y de los vizcaínos como un linaje común, con el derecho de familia sancionado por el Fuero:

«Esta república vizcaína se presentaba también como comunidad de hidalgos porque poseía en su derecho propio los mecanismos y previsiones pertinentes para asegurar en la familias hidalgas la transmisión del patrimonio doméstico, de la

30 Portillo, o.c., p.429-430.

31 Portillo, o.c., p. $430-432$.

Hispania, LXI/3, núm. 209 (2001) 879-906 
casa y tierra. El Fuero era al respecto la mejor evidencia al proteger en los matrimonios, ventas, permutas y herencias la raíz de esos patrimonios. Toda la raíz de Vizcaya (decía el Fuero en la Ley I del Tít.XX) es troncal, esto es, toda la tierra de Vizcaya estaba distribuída en una serie de troncos o familias a los que el derecho vizcaíno aseguraba la posesión de la raíz, de la tierra y casa...Si la tierra toda de Vizcaya era solar conocido, útero de nobleza colectiva de sus gentes, los vizcaínos eran nación de familias, de troncos y raíces, de patrimonios domésticos perfectamente identificables por su permanencia. Eran las casas que nunca morían en Vizcaya»32.

Guipúzcoa no obtuvo hasta bastante más tarde que Vizcaya, hasta la Real Provisión de 1610, un explícito reconocimiento de la hidalguía territorial por el Monarca, pero su imagen «legendaria» como república de hidalgos había empezado a elaborarse mucho tiempo antes, al menos desde los intentos iniciados en 1527 por fijar el derecho guipuzcoano. Un mojón importante en ese proceso ideológico lo puso el Bachiller Juan Martínez de Zaldibia, en 1564, con la publicación de su Suma de las cosas cantábricas y guipuzcoanas ${ }^{33}$. Tras narrar la llegada de Túbal a Vasconia, "la más antigua nación de España», introduciendo «la nobleza en el mundo", relata Zaldibia cómo han conservado los vizcaínos sus «leyes habidas en la ley de naturaleza» y su «lengua primera», el euskera, "grande argumento de no haber sido señoreada»: en efecto, "dos veces vencieron a los romanos y quedaron libres de sujeción», resistiéndose asimismo después a visigodos, suevos y alanos.

«Convida mucho a esta gente —concluye Zaldibia-la estima que hacen de su limpieza y linajes, de que se precian hasta los rústicos y pastores; en especial se jactan mucho de baber siempre sido apartados de herejías, con judios, moros ni infieles nunca mezclados, y haber siempre guardado el puro nombre cristiano» 34 .

De esta pureza de sangre deduce Zaldibia la nobleza vasca, y de la nobleza de «los de esta tierra» hace descender a «las familias nobles de los españoles y sus generosas prosapias y nacimiento», incluyendo a "los reyes de España». De ahí y de lo que alega como fundamento adicional de la bidalguía colectiva:

«Pues, como estas Casas de fuera de las villas fueron edeficadas por los hijosdalgo que fueron los primeros pobladores de la tierra y retienen sus apellidos an-

32 PORTILlo, o.c., p.433.

33 Cito por la Edición de Fausto Arocena, San Sebastian, 1945.

34 Añade: «Y si algún judío por negocios fuere a aquella tierra, no le era lícito tardar en un lugar más de tres días y en toda la región más de trece, de donde se seguía que, en oyendo los muchachos el nombre de judío, se espantaran no menos que si fuera de otra especie que la humana, y aún tienen privilegio para que ninguno de los nuevamente convertidos a nuestra santa fé católica pueda morar en aquella tierra». 
tiguos sin que jamás hubiesen pechado, claro es que éstas son los solares conocidos antiguamente, y así los descendientes de ellas se llaman bijosdalgo de solar conocido e infanzones...porque en la Provincia todos son hijosdalgo y no hay tormento».

La secuencia «mitológica» que establece Zaldibia («hijosdalgo de solar conocido» edificando sus Casas - los «solares conocidos antiguamente»- «fuera de las villas», y legando su hidalguía a sus descendientes que pueblan las villas) mixtifica e invierte el proceso histórico real tal y como está sobradamente documentado, por ejemplo, en la villa de la que tanto el bachiller Zaldibia como su padre y su tío fueron alcaldes, Tolosa, la primera de las villas guipuzcoanas en obtener del Rey la exención universal de impuestos y pechas.

En 1326, los tolosanos solicitaron y obtuvieron del Rey ese privilegio, reconociendo la diferencia entre quienes eran hidalgos y quienes no lo eran, y pidiendo la extensión a todos los villanos del privilegio de inmunidad «segunt que lo son fijosdalgo que agora moran». En 1374, en queja por no haber sido respetado dicho privilegio, insisten en lo mismo, pero ahora alegando «que la dicha villa es poblada toda de omes fijosdalgo et que son avidos por omes fijosdalgo por la corte del dicho rey nuestro padre». Lo que en 1326 era petición de ser tratados como hidalgos se convierte en 1374 en reivindicación de haber sido siempre hidalgos. Y lo que historicamente fue extensión a la tierra llana, durante la segunda mitad del siglo XIV y todo el XV, de la exención tributaria y de la hidalguía colectiva concedida a las villas, se convierte legendariamente en poblamiento de las villas por hidalgos nacidos en solares nobles «fuera de las villas» y «conocidos antiguamente». El mito neutraliza la historia y establece una continuidad entre el presente y los orígenes.

En Zaldibia nos encontramos ya definida la hidalguía colectiva o nobleza universal vasca como algo basado en la descendencia de Túbal, preservado mediante la limpieza de sangre (lo que Sabino Arana llamará «pureza de raza»), la fidelidad al cristianismo y la invencibilidad vasca, como algo definido por el arraigo en una casa solar y patentizado en los apellidos que lo demuestran.

La conversión por Zaldibia de los «apellidos antiguos» en signo revelador de hidalguía y, a su través, de limpieza de sangre — que se corresponde con la conversión por Sabino Arana de los «apellidos euskéricos» en indicio de «pureza de raza» y en requisito imprescindible para ingresar en el PNV- es otro caso flagrante de inversión «mitológica» de un proceso histórico.

Como el propio apellido del Bachiller atestigua —-Martínez de Zaldibia-, todavía en el siglo XVI no se había producido el proceso de cambio del sistema de denominación que se generaliza en los siglos XVII y XVIII como consecuencia de la conquista de la hidalguía colectiva y del paso correlativo de la primacía de la filiación al primado de la residencia (del parentesco a la territorialidad): precisamente porque los apellidos se convierten en indicio de hidalguía y porque la hidalguía se fundamenta en la proveniencia de una Casa-Solar sita en tierra vasca, empezarán las familias «vizcaínas» a denominarse y a ser conocidas por

Hispania, LXI/3, núm. 209 (2001) 879-906 
el nombre euskérico de la Casa en que han nacido; es decir, sustituirán el patronímico - e incluso, en una fase intermedia, su conversión en heredado, en epónimo antepuesto a un topónimo para formar un apellido compuesto transmitido a lo largo de las generaciones- por un toponímico, y las referencias inmediatas o lejanas al «nombre del padre» (Martínez, «hijo de Martín»; Pérez, «hijo de Pedro»; etc.) serán olvidadas y desaparecerán para ser sustituidas por referencias exclusivas al lugar de nacimiento, al nombre del caserío originario ${ }^{35}$.

Volviendo a Zaldibia, digamos que su fundamentación de la nobleza universal vasca en el doble pilar de la limpieza de sangre y la proveniencia de solar antiguo en tierra vasca, equivale a convertir a todos los vizcaínos y guipuzcoanos en miembros de un solo linaje noble, de un único clan familiar, y al territorio de Vizcaya y Guipúzcoa en una sola Casa-Solar, noble y fuente de la nobleza de quienes en ella nacen.

Baltasar de Echave no duda en hacer explícitas estas conclusiones, y en sus Discursos de la Antiguedad de la Lengua Cántabra Bascongada (1607) ${ }^{36}$, dice, refiriéndose a los solares y casas de Guipúzcoa:

«Aunque se han transferido unos en otros, mudándose unas familias en otras, no quita que siendo todos ellos unos, y parientes, sean unos mismos los que en los tales solares y casas subceden, aunque sea por vía de compra; porque, como estas Prouincias sean muy limitadas en si, no an permitido mezclarse, en general ni particular, con gente o nación estraña, ni no limpia e hidalga...de que se sigue ser todos ellos deudos...no tan solamente son estas casas y solares de notorios hijosdalgo de sangre, y solar conocido, si no que también y sobre todo lo dicho son estas Provincias un Solar conocido y notorio de nobles bijosdalgo; y esto con tanta verdad que con solo prouar ser naturales de padres y aguelos, de tiempo inmemorial originarios de estas dos Provincias Vizcaya y Guipúzcoa, basta para sacar executoria...y los tengan por bijosdalgo de sangre, de solar conocido".

Lo que con toda esta construcción doctrinal se persigue es hacer sinónimos limpieza de sangre y nobleza de solar, identificando ambos con nacimiento en tierra vasca y con descendencia de Túbal: nacidos en un único Solar noble, todos los vascos son parientes, miembros de un único clan, de una sola "gran familia».

La más clara y coherente manifestación de esta consideración de Gupúzcoa (y lo mismo cabe decir, como hemos visto, de Vizcaya) como un único Solar noble, y de todos los guipuzcoanos —o vizcaínos- como pertenecientes un solo Linaje, es la tesis de Guipuzcoa como gran mayorazgo bistórico que defiende el

35 Hasta tal punto llegó el primado de la residencia en la denominación de las familias que, en muchos casos, bastaba el traslado a otro Caserío - Etxe- para que, en el plazo de una sola generación, los miembros de la familia pasaran a ser denominados con el nombre de la Casa y no con el apellido del padre: los hijos de un Goenetxea nacidos en el Caserío Barrenetxea llevarían el apellido Barrenechea.

36 Ed. Gran Enciclopedia Vasca, 1971. 
Padre Larramendi S.I. en sus Conferencias curiosas sobre los Fueros de Gupúzcoa ${ }^{37}$ : la historia guipuzcoana se inició cuando «Dios por su voluntad y dirección dividió el mayorazgo total de la tierra en otros mayorazgos menores que adjudicó expresamente a los hijos y nietos de Noé»; tras la confusión de lenguas, Túbal y sus hijos se convirtieron en «los ascendientes y primeros pobladores deste pais y mayorazgo que hoi se llama Guipúzcoa», estableciéndose en él «sin obligación de pagar pechas, gabelas y tributos...con una nobleza de sangre tan pura y tersa que no la ha habido maior, y fue el principio de toda la nobleza de sangre española». Además, el mayorazgo guipuzcoano ha sido el único en mantener estos bienes fundacionales e inalienables, conservando «intactos sus primeros mayorazgos, sus leyes y libertades», que no son otras que los Fueros.

En un claro antecedente de Sabino Arana, el jesuita vincula la idea de una nación vasca con derecho a la independencia a la idea de nobleza de sangre o «pureza de raza»:

«¿Qué razón hay, vuelvo a decir, para que esta nación privilegiada no sea nación aparte, nación por sí, nación entera e independiente de las demás? ¿Por qué tres provincias en España (y no hablo ya del reino de Navarra) han de estar dependientes de Castilla - Guipúzcoa, Alava y Navarra- y otras tres dependientes de Francia - Labort, Zuberoa y baja Navarra-?...Todo gupuzcoano que viene de alguno de los solares de Gupúzcoa, siempre ha sido noble, siempre lo es y siempre lo será...Esta nobleza de sangre les viene por herencia y suben con ella con la mayor limpieza del mundo hasta los primeros pobladores de España. No se la han dado los reyes, que la tienen de muy arriba y de más antiguo...De ahí que no se admita por vecino de algún pueblo de Guipúzcoa al que no es hidalgo conocido...No son admitidos para vecinos ni moradores, ni para residencia permanente, ni judíos, ni moros, ni los que tienen alguna raza de ellos, ni mulatos ni negros».

Creo que se puede concluir que — por lo que se refiere a la «raza vasca»lo que he propuesto llamar «concepto genealógico de raza» (es decir, la categorización de «los vascos» como grupo de parentesco, como «clan», como «gran familia» descendiente de un antepasado común) empieza a elaborarse con Poza y Zaldibia en el siglo XVI, madura con Echabe en el XVII y se consuma en el XVIII con Larramendi, quien además incorpora ya explicitamente a la construcción doctrinal sobre la nobleza de sangre de los vascos el término raza.

Es decir, la «raza vasca», concebida en términos sustancialmente idénticos a los que expone Sabino Arana, es un constructo ideológico plenamente elaborado desde al menos el siglo XVIII y cuyos fundamentos se sientan en el XVI. Y cumple además una importante función social como pilar central de una «mitología» muy difundida que legitima la hidalguía colectiva y la legislación foral.

37 Citado por Fernández Albadalejo en «Manuel Larramendi, la particular historia de Guipúzcoa», Saioak, nº $1,1977$.

Hispania, LXI/3, núm. 209 (2001) 879-906 
Ese corpus doctrinal al que, desde Poza en Vizcaya, y entre Zaldibia y Larramendi en Guipúzcoa, contribuyen una legión de apologistas del euskera, de los Fueros y de la nobleza de sangre, es la fuente principal de la que brota la «raza vasca» sobre la que se sienten obligados a teorizar los antropólogos racialistas europeos del siglo XIX y a la que remiten tanto la concepción ideológica de Sabino Arana como los desarrollos científicos de Telesforo de Aranzadi.

Hemos visto cómo llega a categorizarse la raza vasca como «clan único», como «gran familia» asentada en una sola Casa-Solar, en un «gran mayorazgo» que se confunde con la tierra vasca. Nos queda por ver cómo se configuran paralelamente las familias que constituyen esa "gran familia», los linajes en que se segmenta el «clan único», los Caseríos y grupos domésticos que se dividen el "gran mayorazgo" vasco. Nos queda por ver cuál es el proceso histórico de configuración de la familia autoritaria vasca, responsable, según Todd, del desarrollo de un racismo heterófobo tradicional-comunitarista.

\section{LINAJE, FAMILIA, RAZA}

El tipo de familia autoritaria que Todd atribuye a los vascos es efectivamente, como vamos a ver, la familia tradicional predominante en el País Vasco durante los siglos XVI-XIX. Sus características específicas y su importancia se hacen más evidentes si las situamos en una perspectiva diacrónica y las comparamos con la configuración de la familia y el parentesco inmediatamente anterior y posterior.

El primer período histórico sobre el que tenemos información suficiente como para reconstruir de modo fiable las estructuras del parentesco en el País Vasco es el correspondiente a la sociedad banderiza de la Baja Edad Media ${ }^{38}$. La

\footnotetext{
38 No quiero con ésto decir que no haya material arqueológico, epigráfico e histórico para hacer una reconstrucción hipotética plausible del parentesco «vasco» en la época romana e incluso pre-romana, empezando por el controvertido texto del geógrafo griego Estrabón sobre la «ginecocracia» cántabra, sobre el que tantas aventuradas tesis acerca del supuesto «matriarcado vasco» se han construido. En Milenarismo Vasco, Tercera Parte, Capítulo II.2. "Crítica de la sinrazón matriarcal», discuto en detalle - en el marco de una crítica de las tesis matriarcalistas - la documentación existente y las reconstrucciones que sobre esa base, y una buena cantidad de especulación gratuita, se han realizado. La historia de las estructuras del parentesco y de la familia en el País Vasco medieval que a continuación expongo recoge básicamente las tesis al respecto desarrolladas en Milenarismo Vasco, en el capítulo citado y también en el capítulo 2 ( $\mathrm{La}$ lucha de bandos en el País Vasco. La crisis bajomedieval en Vizcaya) de la Segunda Parte, dedicada a «los herejes de Durango». Desde entonces (1982) hasta hoy ha sido mucha y muy importante la investigación histórica realizada sobre ese período, siendo algunas de las más interesantes aportaciones realizadas, como las de Jose Antonio Marín Paredes, fruto de la incorporación al análisis histórico de aportaciones teóricas provenientes de la antropología social, especialmente de la antropología del parentesco. Obviamente, he procurado tener en cuenta en el resumen que sigue los resultados de esa investigación reciente, aunque creo que afectan, más que a los rasgos definitorios de las estructuras parentales, a la imagen
} 
sociedad vizcaíno-gupuzcoana de esa época era una sociedad jerarquizada y estratificada: los seniores que disfrutaban de poder, riqueza, autoridad y patrimonio, se situaban por encima de sus milites y bomines, vasallos que les debían obligaciones no siempre especificadas, y todos ellos se situaban por encima de los collazos, encargados de hacer producir las tierras y satisfacer una serie de rentas a sus señores. Pero junto a esta división horizontal, una de cuyas fronteras era la posesión o ausencia de hidalguía, el principio fundamental de organización social era el parentesco:

«ser pariente identificaba y establecía las vinculaciones y los tratamientos sociales...ser mayor distinguía, en una comunidad entrelazada por medio razones parentales, quien despuntaba en condición y valía comunitaria...un modo de hacer comunidad en la que su estructura estaba definida, interpelada y usada por medio del parentesco»39

y el criterio básico de estructuración parental era la división vertical de la sociedad en linajes patrilineales, tanto si la vinculación al linaje se basaba en lazos de consanguinidad o afinidad, como si reposaba en lazos de dependencia feudal.

Los linajes se hallaban formados en principio por el conjunto de consanguíneos por línea paterna descendientes de un antepasado al que se consideraba primer poblador de un solar. Las raíces de un linaje eran, por consiguiente, una primera Casa-Solar. Dentro del linaje se distinguía una rama principal o troncal, constituida «idealmente» - de hecho, no siempre ni necesariamente- por la sucesión de primogénitos, y ramas colaterales que podían en un determinado momento fisionarse, constituir una nueva casa-solar, y fundar así un nuevo linaje secundario. Entre estos diversos linajes existían unos fuertes lazos de solidaridad agnática que les llevaban a agruparse bajo la jefatura y dirección de un Pariente Mayor, que era por lo general el representante de la línea troncal ${ }^{40}$.

La alianza o afinidad jugaba también un importante papel en ese sistema basado en la filiación, llegando a romper en ocasiones la solidaridad agnática y provocando incluso un trasvase de linaje, aunque la mayoría de las veces sólo se llegaba a un cambio de bando, siendo ya los bandos unidades sociales más am-

\footnotetext{
pasada, un tanto esquemática y simplificadora, de la polifacética conflictividad social del período y de las relaciones entre las villas y los linajes (entre el medio urbano y el medio rural). Una magnífica síntesis del estado actual de la investigación sobre el tema y una bibliografía completa sobre el mismo en Jose Ramón Díaz de Durana y Ortiz de Urbina (ed.), La lucha de bandos en el País Vasco: de los Parientes Mayores a la bidalguía universal. Guipúzcoa, de los bandos a la Provincia (siglos XIV a XVI), Servicio Editorial Universidad del País Vasco, Bilbao, 1998.

39 José Antonio Marín Paredes, «¿Qué es un Pariente Mayor? El ejemplo de los señores de Oñaz y Loyola», en Diaz de Durana (ed.), La lucha de bandos en el País Vasco, o.c., p.209.

40 De hecho, la figura del Pariente Mayor no se establece de modo automático, sino que se le exigen una serie de cualidades en relación con las responsabilidades que su puesto le asigna, y la parentela goza de un cierto márgen de libertad para su elección.
}

Hispania, LXI/3, núm. 209 (2001) 879-906 
plias a los que no cabe llamar clanes porque se basaban en la comunidad de intereses más que en la presuposición de una filiación común.

La política matrimonial obedecía sobre todo al deseo de asegurar y engrandecer la posición del linaje-solar, y daba lugar a una compleja constelación de linajes basada en el entrecruzamiento, no siempre claro ni sobre todo estable, de solidaridades agnáticas y congnáticas. La condición de posibilidad de esta política matrimonial eran las normas que regulaban la herencia: aunque se registraban excepciones, se tendía a la transmisión única e indivisa del patrimonio, y existía la costumbre - más tarde sancionada jurídicamente por el Fuero- de que el cabeza de linaje designara libremente al heredero en virtud de su mayor o menor capacidad para servir a los intereses del linaje-solar. Esta libertad de elección no excluía a las mujeres, y no era excepcional el caso en que una mujer era designada heredera para facilitar así la búsqueda, mediante matrimonio, de un cabeza de linaje considerado idóneo.

Aunque el matrimonio era formalmente monógamo, el concubinato estaba prácticamente institucionalizado $\mathrm{y}$, dada la importancia de la producción de hijos para incrementar el poder y «el más valer» del linaje, era práctica común tomar «mancevas de linaje» para la producción de bastardos.

El patrimonio bumano de un linaje se hallaba compuesto, en primer lugar, por el conjunto de consanguíneos por línea paterna - muchos de ellos bastardos-, a los que se añadía con frecuencia una parentela cognática incorporada al linaje por vínculos de afinidad. A esta amplia parentela había que sumar los atreguados, encomendados y lacayos, sometidos igualmente a la autoridad del $\mathrm{Pa}$ riente Mayor y vinculados al linaje por distintos lazos de dependencia personal y colectiva.

Las rentas de los Parientes Mayores derivaban de muy distintos orígenes: la explotación directa del suelo, la ganadería, los tributos reclamados a los encomendados, el uso y abuso de supuestos derechos de peaje o portazgo, el disfrute de cargos como el de preboste, las dádivas que algunos pueblos y aldeas les daban "por cortesía», las meras rapiñas y los diezmos eclesiásticos que cobraban como patronos de diversas iglesias ${ }^{41}$.

Este último punto es importante, porque indica que, durante la Edad Media vasca - antes del arraigo de las Ordenes Mendicantes y antes, sobre todo, de la ofensiva pastoral que los jesuitas emprendieron después de Trento- el clero, de nula formación doctrinal, casi siempre amancebado y carente de con-

41 Cf. José Ramón Díaz de Durana Ortiz de Urbina, «Aproximación a las bases materiales del poder de los Parientes Mayores guipuzcoanos en el mundo rural: hombres, seles, molinos y patronatos», en Diaz de Durana (ed,), o.c., p.237: «Por último me ocuparé de los patronatos sobre las iglesias gupuzcoanas en manos de los señores. Se trata, en mi opinión, de una pieza clave en el rompecabezas de la evolución de la sociedad guipuzcoana. Sobre esos patronatos, que implicaban la percepción de los diezmos y primicias, se apoyó con fuerza el control, también ideológico en este caso, de los Parientes sobre los guipuzcoanos». 
trol episcopal ${ }^{42}$, dependía de los Parientes Mayores y de los respectivos cabezas de linaje, que fundaban monasterios o «iglesias propias", las encomendaban a clérigos dóciles (con frecuencia los segundones de la pequeña nobleza) y se apropiaban de los diezmos, reservando para el cura la parte «congrua». Es decir, también el clero dependía de los linajes, la organización eclesial estaba engullida por, y subordinada a, las estructuras de parentesco.

El resultado de esta «lógica parental» era que

«en cada lugar la población se organizara en soleres vinculados entre sí...el trato intersolares estaba medido y practicado por un uso concreto del parentesco. Un uso que debía consistir en la forma de establecer alianzas entre solares, esto es, generar matrimonios dentro de cada comunidad, y en la manera de concretar el modo de transmisión del patrimonio de cada solar...En consecuencia, el solar era el sujeto principal de cada comunidad y el fundamento de su estructuración interna. De ahí que sea posible definir a estas comunidades como comunidades de solares» ${ }^{43}$.

Tras un prolongado período conocido como «guerras de bandos»-que es sólo una de las muchas y variadas manifestaciones conflictivas, la mejor conocida y más «historiada», de la crisis bajomediaval en el País Vasco- los Parientes Mayores fueron derrotados por la alianza entre la Corona y las Hermandades de las villas, y la sociedad banderiza, cuyas estructuras de parentesco acabamos de caracterizar, experimentó una gran transformación cuyo símbolo más notorio fue la conquista de la hidalguía colectiva y la institucionalización de los Fueros.

$\mathrm{Si}$, después de esa época, podemos hablar de la sociedad tradicional vasca del Antiguo Régimen como de un todo relativamente uniforme y constante es porque, entre los siglos XVI y XIX, se mantiene en Vizcaya y Guipúzcoa una estabilidad estructural que los cambios históricos y económicos, por importantes que sean, no alteran en lo esencial. Su configuración territorial permanece estable, su sistema jurídico-político (los Fueros) permanece estable, y también permanece estable su modelo económico de desarrollo, basado en una agricultura de autoconsumo deficitaria (incapaz de satisfacer las necesidades alimenticias de la población), una demografía emigratoria y la dependencia del comercio. Pese a los importantes cambios que a lo largo de tres siglos se registran en la actividad comercial, en su relación con el desarrollo industrial, e incluso en el régimen de propiedad de la tierra, la sociedad tradicional vasca tiene un techo estructural, una columna vertebral, un esqueleto agrario que permanece in-

42 La literatura de la Baja Edad Media abunda en denuncias de estos «clérigos facinerosos», así como del concubinato y amancebamiento de la clerecía; Tetzel y Pierre de Lancre nos informan de que los curas vascos «conocían a las mujeres» — con fecundos resultados, dada la cantidad de hijos de curas que había en la Guipúzcoa del siglo XVI- y diversos mandatos eclesiásticos prohibían a los sacerdotes asistir a los bailes públicos y condenaban comilonas, sacrificios de carneros en el interior de las iglesias y otra serie de actos más propios de unas saturnales que del ritual cristiano.

43 Marín Paredes, o.c., p. 212 y 215 .. 
cambiado en tanto que dependiente de las características ecológico-demográficas del país: la explotación familiar destinada al autoconsumo, con sucesión troncal y heredero libremente elegido (el Etxe o Casa entendida como la unidad de familia, edificio, utensilios, aperos y tierra que permanece idealmente inalterable a través del tiempo).

En el ámbito de las estructuras familiares y de parentesco, ese cambio desde la sociedad banderiza a la sociedad tradicional centrada en el Etxe, puede caracterizarse globalmente como un paso de la primacía de la filiación al primado de la residencia, o también como una transición del parentesco amplio a la territorialidad a la hora de definir la identidad de los agentes sociales.

El estudio de las «probanzas de hidalguía» en la sociedad tradicional vasca ${ }^{44}$ indica que se sigue alegando pertenencia al grupo de parentesco por filiación patrilineal (el linaje se perpetúa por línea de varón y los hijos pertenecen al linaje del padre) pero también que cobra más importancia el parentesco bilateral, pues con frecuencia se alega posesión de Casa-Solar, por parte de los antecesores, por vía tanto paterna como materna.

Los casos de «herencia femenina» producen con frecuencia la no coincidencia de la patrilinealidad del linaje con la línea de transmisión de un solar o vínculo, lo cual introduce una diferencia entre el solar como «suelo con el que se identifica un tronco de varones» (un linaje) y el solar como conjunto de tierras y propiedades vinculadas en las que vive una familia o comunidad doméstica. La causa de esta posible diferencia es doble: por una parte, el matrimonio, la afinidad, que actúa como injerto o puente por el que el solar se trasvasa a otro linaje, en especial si se transmite por línea femenina; por otra parte, la fundación de nuevos vínculos por ramas segundonas del linaje, que generan un desdoblamiento del tronco del mismo. El quid de la cuestión está pues en la transmisión del solar.

La pauta básica y determinante de dicha transmisión es la troncalidad con indivisión del patrimonio que caracteriza a la institución del mayorazgo. El seguimiento de esta norma de heredero único con prohibición de repartir el patrimonio familiar puede adoptar diversas formas: el Fuero acepta la libre designación de heredero, por lo cual el heredero puede ser o no el primogénito y puede ser varón o hembra. En virtud de esta libertad en la elección de heredero por los padres se registran casos de hembra tronquera o mayorazga, cuya significación es preciso analizar a la luz de las reglas del matrimonio.

El objetivo de todo matrimonio es el mejoramiento y consolidación del solar y sólo por referencia a dicho objetivo se explica la ley de libre designación de heredero: dada la costumbre de la transmisión «propter nuptias» del solar, que obliga a los padres a transmitirlo en el momento de la boda del hijo mayoraz-

44 Seguimos aquí a Jesús Arapal, La sociedad tradicional en el País Vasco, L. Haranburu Ed., San Sebastián, 1979. También, del mismo autor, «Estructuras familiares y de parentesco en la sociedad estamental en el País Vasco», en Saioak, año 1, nº 1, 1977. 
go, dicha ley permite la elección por los padres de ese momento, su no supeditación a la edad favorable para el matrimonio del primogénito o de los hijos varones, la posibilidad de escoger la circunstancia más conveniente al solar-para el establecimiento de una alianza y la consiguiente supeditación a ese objetivo de la estrategia matrimonial a seguir con hijos e hijas. La referida ley funciona, por tanto, como control previo a la selección de cónyuge, como robustecimiento de la autoridad paterna en la toma de estado, como supeditación de la transmisión hereditaria a los intereeses familiares confundidos con el provecho del solar.

Desde el punto de vista de las reglas del matrimonio, la designación de mayorazga, siempre excepcional, parece obedecer a una estrategia de cara al mercado matrimonial orientada a la consolidación de un solar. Pueden ser múltiples los motivos que en determinadas circunstancias impulsen a una familia a incrementar las posibilidades de buen matrimonio de una hija, concediéndole el vínculo y permitiendo que el solar se transvase de linaje a cambio de su conservación y mejoramiento, pero siempre, en tal caso, el linaje se «sacrifica» al solar.

En Los vascos, Julio Caro Baroja insistió en la perduración de esta primacía del solar en el medio rural vasco aún después de que la abolición de los fueros suprimiera la norma de mantener el patrimonio indiviso, y aún dèspués de que la industrialización y la urbanización dejaran sentir sus poderosos efectos sobre las estructuras familiares y de parentesco. De todos modos, la ausencia de estudios suficientes sobre las transfomaciones de esas estructuras en el medio urbano e industrial del País Vasco desde finales del siglo XIX nos impide ir mucho más allá de su caracterización general en base a tres tendencias principales: el predominio progresivo de la familia nuclear, elemental, o conyugal (formada por una pareja casada y su descendencia) con pérdida de la unidad residencial trigeneracional; la pauta neolocal de residencia post-marital; y el reparto igualitario de la herencia entre todos los hermanos exigido por el Código Civil burgués que sustituye a los Fueros.

La primacía del solar en el medio rural vasco la corrobora W.A.Douglass, cuyo análisis de las relaciones familiares contemporáneas en Murélaga y Echa$\operatorname{lar}^{45}$ tiene además, para nosotros, el interés adicional de incluir el estudio de sus principales núcleos conflictivos. Para Douglass, hay dos categorías actuantes para los vascos, familia y etxekoak («los de casa»), claramente delimitadas en su conciencia y en su comportamiento, que no coinciden en su composición con el grupo residencial habitualmente llamado, desde Le Play, familia troncal («agrupación corresidencial que abarca a ego y a su cónyuge, a sus descendientes solteros, a los padres de ego y - eventualmente- a los consanguíneos solteros de ego»). En los etxekoak se incluye, además de a los que efectivamente residen en el Etxe o Casa, a los solteros ausentes que conservan el derecho a volver y a residir nuevamente en ella; mientras que, por su parte, la familia — primer círculo

45 Douglass, W.A.: Muerte en Murélaga, Barral Ed., Barcelona, 1973, y Oportunidad y éxodo rural en dos aldeas vascas, Ed.Auñamendi, San Sebastian, 1977, esp.tomo I, cap.3. 
de la parentela, que aparece claramente separado de otro círculo concéntrico más amplio, conocido como familiakoak, «los de la familia»- aparece como «una categoría parental ego-específica que comprende el cónyuge de ego, sus hijos, hermanos y padres, vivos o muertos, residan o no con ego y (en el caso de hermanos o hijos) estén casados o solteros».

La composición típica del grupo doméstico (aquellos etxekoak efectivamente residentes en el caserío) es trigeneracional: un núcleo central formado por una pareja casada activa (etxekojaun y etxekoandria), una pareja retirada o semiretirada (que son los padres del etxekojaun o de la etxekoandria, según que la residencia del matrimonio entre ellos haya sido patrilocal o matrilocal) y los descendientes solteros de ambas parejas (cuando los hay se incluye también a adoptados y a criados); la norma «ideal» es que se dé correspondencia biunívoca entre grupo doméstico y caserío. Entre los factores que con más frecuencia condicionan que no se cumplan esas normas «ideales» o típicas está la adopción de una pauta de residencia neolocal (los recién casados se trasladan a un nuevo caserío) y la violación de la norma fundamental por antonomasia: la indivisión del patrimonio, o mejor dicho, la indivisión del Etxe (entendido como la unidad, inalterable a través del tiempo, del edificio, los utensilios de la casa, los aperos y las tierras).

Es esta norma básica y las normas de sucesión hereditaria que de ella derivan lo que, todavía a mediados de este siglo, seguía determinando la estructura fundamental del grupo doméstico rural. En contra de lo legalmente establecido por el Código Civil español, en amplias zonas del País Vasco siguió imperando la norma de libre designación de heredero único, ligada a la indivisión del patrimonio, norma que la costumbre local matizaba en uno u otro sentido preferencial, decantándose habitualmente por la primogenitura masculina (o al menos, casi siempre, por herederos varones), pero respetando el criterio supremo de escoger al heredero más conveniente, es decir al que reuniera el conjunto de cualidades más idóneas para hacer prosperar el Etxe.

La elección de heredero es determinante de la pauta de residencia: por lo general, esta será patrilocal cuando en el matrimonio el heredero es el marido, matrilocal cuando lo es la esposa y neolocal cuando no lo es ninguno de los dos. Y la residencia a su vez determina la línea de filiación: ésta es, por tanto, utrolateral, es decir que «el individuo puede integrarse al grupo doméstico natal de su padre o de su madre, pero no a ambos simultaneamente...la filiación está determinada por la línea familiar del padre que continúe viviendo en su casa natal (es decir, el anterior heredero)».

Además de por descendencia se puede ingresar en un grupo doméstico por matrimonio, por vínculos de parentesco ficticio o adopción y por consentimiento (criados, etc.). Por lo que se refiere a la alianza o afinidad, hay que destacar varias cosas:

Mientras que, para el heredero, el matrimonio marca el comienzo de la transmisión a sus manos del patrimonio doméstico (su conversión en etxekojaun o etxekoandria) y para su cónyuge supone la incorporación al grupo de su mari-

Hispania, LXI/3, núm. 209 (2001) 879-906 
do (o de su esposa), para los no herederos el matrimonio supone la salida del grupo doméstico natal: sólo en cuanto solteros pertenecen a él.

El matrimonio supone para el cónyuge del heredero o heredera un cambio de adhesión, un abandono del grupo doméstico natal para incorporarse con plenos derechos al grupo doméstico del cónyuge heredero. La integración del afín en el nuevo grupo doméstico, identificado con la unidad territorial, es total y absoluta, y se manifiesta en la forma de denominación, en el cambio de apellido, que pasa a ser el del nuevo Caserío.

El matrimonio es un acuerdo entre dos grupos domésticos y sólo se considera consumado cuando hay descendencia.

El vínculo doméstico más intenso y valorado es el matrimonial, tanto el de la pareja «retirada» como el de la que forman el etxekojaun y la etxekoandre; sobre él descansan los cimientos del Etxe y él es el último en romperse en las posibles situaciones conflictivas.

La connotación positiva del vínculo matrimonial conlleva la connotación negativa del vínculo fraterno, manifiesta en la potencialidad conflictiva de las relaciones entre el heredero y sus hermanos, que suele actualizarse en las dos direcciones: como queja del heredero por la vagancia de un hermano o hermana (que tiene derecho a la residencia en el caserío sin que, como contrapartida, sus obligaciones aparezcan claras), y como queja de éstos ante la cuantía de la dote fijada por el heredero.

La otra posibilidad conflictiva intradoméstica de más frecuente actualización es la que enfrenta a la pareja «retirada» y a la pareja «en activo», debido a que la transmisión propter nuptias no lo es ni de todo el patrimonio, ni de toda la autoridad. Algo tan fundamental como la continuidad del caserío depende de que esta conflictividad potencial no llegue a estallar obligando a una ruinosa separación.

La principal función de la ideología familiar (de la familia en cuanto distinta de los etxekoak y del grupo doméstico efectivo) consiste precisamente en amortiguar la conflictividad potencial resultante de la estructuración del grupo doméstico determinada por la regla de sucesión hereditaria: la familia «recubre» las citadas relaciones conflictivas o ambiguas con la afectividad y las pautas de valoración vinculadas a la relación fraterna o paterno-filial, poniendo así en manos del etxekojaun la posibilidad de «manipular sus funciones de familia para conseguir aliviar las tensiones entre sus etxekoak».

En el marco de esta estructura familiar, las relaciones entre sus miembros -que constituyen el modelo inconsciente de relaciones humanas que aprende quien se cría en su seno- están caracterizadas por la asimetría, la ambigüedad del reparto y transmisión del liderazgo y del poder entre generaciones sucesivas, el control completo por los padres de la elección de cónyuge del heredero y, sobre todo, la desigualdad entre hermanos y el «cainismo» simbólico. Sólo uno de los hermanos puede acceder a su realización plena como hombre o como mujer (como etxekojaun o etxekoandre), ese destino no depende de su voluntad ni está escrito desde su nacimiento (depende de la libre decisión de sus padres) y 
el precio de su cumplimiento es la exclusión, la eliminación, de sus hermanos «segundones», condenados a un destino secundario: soltería dependiente si quieren conservar la residencia en el Etxe (mutilzarra o nezkazarra), emigración con expectativa de retorno glorioso («indiano») o cura.

Las alternativas de lo que se ha llamado «la pauta del segundón», producida por la institución del heredero único, son muy ilustrativas de la dirección que marca la «ideología de la familia» manipulada por el etxekojaun para amortiguar y dar salida a los conflictos generados por la estructura familiar. El conflicto entre las dos parejas casadas que se reparten el poder se resuelve o se amortigua invocando, por encima de los deberes mutuos que se deben padres e hijos, el supremo interés, e incluso la sacralidad, del Etxe que da identidad a los etxekoak y les une a los «antepasados» (unos «antepasados» que no se establecen por filiación, sino por residencia pasada en el mismo Etxe, en «la misma tierra»). Es también la Casa, las exigencias que su conservación y engrandecimiento imponen, lo que legitima la renuncia, el sacrificio cainita, de los «segundones», lo que les invita a mantener la soltería en el «exilio» - a no casarse con «extranjeras»- para continuar siendo uno de los etxekoak, y lo que les impulsa a preservar la expectativa de retorno glorioso a la tierra (es decir, enriquecido y, por lo tanto, revalorizado a efectos de que algún Etxe decida nombrar heredera a quien, al cararse con él y aportar con ella el Caserío familiar, le convertiría en reconocido etxekojaun). En cuanto al «segundón» que se convierte en cura, no sólo no pierde - en virtud de su soltería - la condición de miembro de los etxekoak, su identidad micro-grupal, sino que conecta ésta, a través de la religión étnica que es el catoliscismo vasco tradicional, con la identidad nacional y racial que arraiga en la «mitología» de la nobleza universal.

Si aceptamos el análisis de Todd sobre los efectos axiológicos e ideológicos desigualitarios, diferencialistas y heterofóbicos de una estructura familiar como la descrita - a la que él designa como familia autoritaria - nos encontramos además, en el caso vasco, que el único modo de aliviar las tensiones generadas en su seno por el «asesinato simbólico del hermano» y la desigualdad interna, es canalizarlas mediante una ideología «familiar» que, como vimos, concibe la fraternidad y la igualdad como fundadas en la nobleza de sangre, de tal modo que «familia autoritaria» $y$ "raza genealógica» suman sus efectos para predisponer a los vascos del Antiguo Régimen que viven en la sociedad tradicional, especialmente en el medio rural, y que se socializan en el marco de su estructura familiar típica, a la adopción de actitudes heterofóbicas y de ideologías racistas.

En ese cóctel explosivo de familia y raza, no podía faltar la religión. El catolicismo tridentino, la autoridad episcopal y la pastoral de las órdenes religiosas, especialmente de los jesuitas, que reclutaron innumerables «segundones» excluídos del Etxe por el heredero único, fue en el País Vasco el más eficaz aliado de la Monarquía y de las autoridades forales, es decir del Estado que comenzó a construirse en el siglo XVI, contra las redes y solidaridades de parentesco en que se basaba el poder de los linajes banderizos y de los Parientes Mayores. 
Y lo fue, no sólo por motivos religiosos, sino también por los más prosaicos motivos materiales, pues el País Vasco no fue una excepción en el proceso histórico, descrito por Jack Goody ${ }^{46}$, que llevó a la Iglesia Católica a edificar las bases económicas y políticas de su poder sobre la transferencia de riqueza y de funciones sociales hacia ella, producida por la prohibición de todas las estrategias de herencia y de solidaridad parental tradicionalmente puestas en práctica por las familias y grupos domésticos en Europa, es decir, por la prohibición de la adopción, del levirato (obligatoridad de casarse con la viuda del hermano muerto), de la poligamia y del concubinato (métodos de multiplicación de los parientes y de producción de herederos).

Al mismo tiempo que instauraba el celibato sacerdotal y el rígido control episcopal del disoluto clero vasco medieval - que escapaba así, junto con los diezmos eclesiásticos, de las manos de los Parientes Mayores-, la Iglesia remodeló las ceremonias religiosas, especialmente los ritos de paso, al objeto de romper cualquier posible simbolización y actualización ritual de los vínculos de parentesco amplio definitorios de los linajes banderizos. Con una estructura familiar recortada en su extensión al mínimo posible permitido por las condiciones ecológico-demográficas de la zona y por las exigencias de una explotación agraria viable, la Iglesia vasca se benefició de un triple desvío: el desvío hacia la jerarquía eclesiástica y las órdenes religiosas del antiguo poder y autoridad sobre el clero de los Parientes Mayores, el desvío de buena parte de los segundones excluídos de la herencia del Etxe hacia sus Seminarios y Noviciados, y el desvío hacia sus arcas de buena parte de la riqueza que anteriormente circulaba por las venas del sistema de parentesco banderizo.

De ese modo, familia autoritaria, pureza de raza y religión católica se configuraron como tres pilares de la sociedad tradicional vasca estrechamente entrelazados que se reforzaban mutuamente. Tiene, por consiguiente, poco de extraño que fuera en el crisol de un "protorracismo religioso" deudor del antisemitismo inquisitorial español, y como derivación de un «concepto genealógico» de raza, como se incubó inicialmente la «raza vasca» de Sabino Arana.

46 The development of the family and marriage in Europe, Cambridge University Press, 1983. 